\title{
Implementation Smart City Concepts for Mobility, Case Study of World Logistic Models on the Smart Principles
}

\author{
Dominika Šulyová $^{1 *}$, Josef Vodák ${ }^{1}$ and Gabriel Koman ${ }^{1}$ \\ ${ }^{1}$ University of Žilina, Department of Management Theories, Faculty of Management Science and \\ Informatics, Univerzitná 8215/1, Žilina, Slovak Republic; Email: dominika.sulyova@fri.uniza.sk, \\ josef.vodak@fri.uniza.sk,gabriel.koman@fri.uniza.sk
}

\section{*Corresponding Author: Dominika Šulyová}

Received: 19 October 2020; Revised: 30 October 2020; Accepted: 5 November 2020; Published: 30 November 2020

\begin{abstract}
The aim of the article is to present the logistic models of world cities, their benefits and limitations, which serve as best practices for others, which are based on a secondary analysis of case studies. The studies were selected on the basis of geographical location, number of transport projects, implementation models for urban logistics, and determining the effects of implementation. In addition to the secondary analysis, the findings of consultants, methods of comparing case studies, summarizing the findings in the discussion, or deductions in drawing a conclusion were also used. The output of the article is a recommended implementation of logistics model for Smart Cities according to world experts, which can be implemented in general for any city, including specific differences for the selected location. The article describes the positive impact of technology in mobility not only for citizens but also for business managers and the city as a whole. The implications of the model, its testing in practice and the observation of implementation benefits and limitations will form a part of further research activities in the future.
\end{abstract}

Keywords: Smart City, mobility, logistic models, management, technology

\section{Introduction}

Robotization, automation, and digitization are changing the way we communicate, live, and spend our free time. The "smart cities" business model involves several stakeholders (government, SMEs, universities, research centres and citizens). Through their mutual support and partnerships, a new digital platform is being built that can improve the quality of life and business.

Mobility is a key element affecting all stakeholders. Inefficient traffic flow is mainly caused by failures, accidents, low or no prediction systems and lack of incorrect information. One solution of these problems is smart technology for Smart City mobility. The net of things, sensors and 
applications can collect big data generated by citizens, business and the city on a daily basis and in real time. Modified processes, strategies and logistic models based on the obtained data streamline not only transport aspects, but also the level of functions of management and decision-making in companies and cities around the world [1-3].

\section{Data and Methods}

The analysis of secondary data in the form of case studies serves to identify the logistic models of Smart Cities and to describe their benefits and limitations. Knowledge of the Smart City concept is supported by relevant arguments from McKinsey Global Institute consultants. Best practices were selected on the basis of the following criteria:

- geographical location, to cover major cities around the world, mainly in Europe and Asia,

- $\quad$ select only those cities that have implemented strategies, projects, innovative processes and logistic models for smart mobility,

- case studies should include information and facts on positive implementation effects and possible limitations of logistic models.

The case studies were then mutually compared, which is presented in the Discussion section together with the summary of the positives and limitations of the models and the conclusion was drawn on the basis of the deduction method.

\section{Results}

"Smart City" was built on a basic three-tier architecture, which is a general concept for the implementation of digital elements in city management [4].

\subsection{Levels of the Digital City}

The technological core contains ICT technologies, smartphones, sensors, action units and controllers, which communicate with each other on the M2M principle, collect data in the field and send it over the network for further processing and analysis. The transmission is based on IP protocols $[4,5]$.

In the application layer, the "raw" data is processed in a structured form. Mobile applications cover the areas of healthcare, transport, energy, or environmental protection (alternative energy sources, etc.) [4].

The presentation layer provides information to the user, ensures communication with the system, management and decision support, and influences changes of behaviour based on the acquired knowledge [4,6]. 


\subsection{Mobility}

According to McKinsey statistics from 2018, cities that are most concerned with the transformation of smart transport are [4]:

- Seattle (North America),

- London (Europe),

- Dubai (Middle East and Africa),

- Sydney (Asia-Pacific),

- Buenos Aires (South America).

The vast majority of cities invest their free funds in mobility (60\%), although no city uses its full potential. Of the 50 cities, 49 implemented real-time navigation systems ( 1 city is preparing a pilot project), 48 prefer the integration of traffic information (2 pilot projects), digital payments (44 cities, 3 pilot projects, 3 cities do not plan to launch a project), parking ( 7 cities, 35 pilot projects, 8 rejections) and predictions (5 places, 4 projects, 41 stagnations). Best practices in the field are world used cases and their logistic models based on Smart Cities approaches [4,7].

\subsection{London}

The London agglomeration has saved more than $€ 251$ billion thanks to introduction of smart mobility at London's Royal Docks. The benefits include obtaining real-time data collected by sensors, fewer accidents, faster troubleshooting. The applications provide a view of transport that perceives mobility as a service. A promising goal is to increase the economic benefits of "smart" London, especially its eastern part [8].

\subsection{Singapore}

The city of Singapore has solved the problem of connectivity for an increased population through a holistic approach. One monitoring is a web portal with traffic information from cameras, sensors, and GPS devices. EMAS and VRS works on the principle of sensors that reports a traffic accident and sends a message to the police, fire brigade and ambulance, which should arrive within 15 minutes of the accident. "Your Speed Sign" are sensors on the tires that monitor the maximum allowed speed, when exceeded, the driver is fined, which results in greater safety and control. The bus information system and the free parking space finder bring value especially for the inhabitants [9].

\subsection{Gothenburg}

The strategy in Gothenburg is based on the seamless supply of products and materials, environmental protection, simple and at the same time efficient logistic processes. Prerequisite for 
success is the cooperation of all stakeholders. Figure 1 shows an example of Stadsleveransen suppliers of shipment for shops and business in the city centre. Their vehicles are equipped with eco-friendly tires [10].

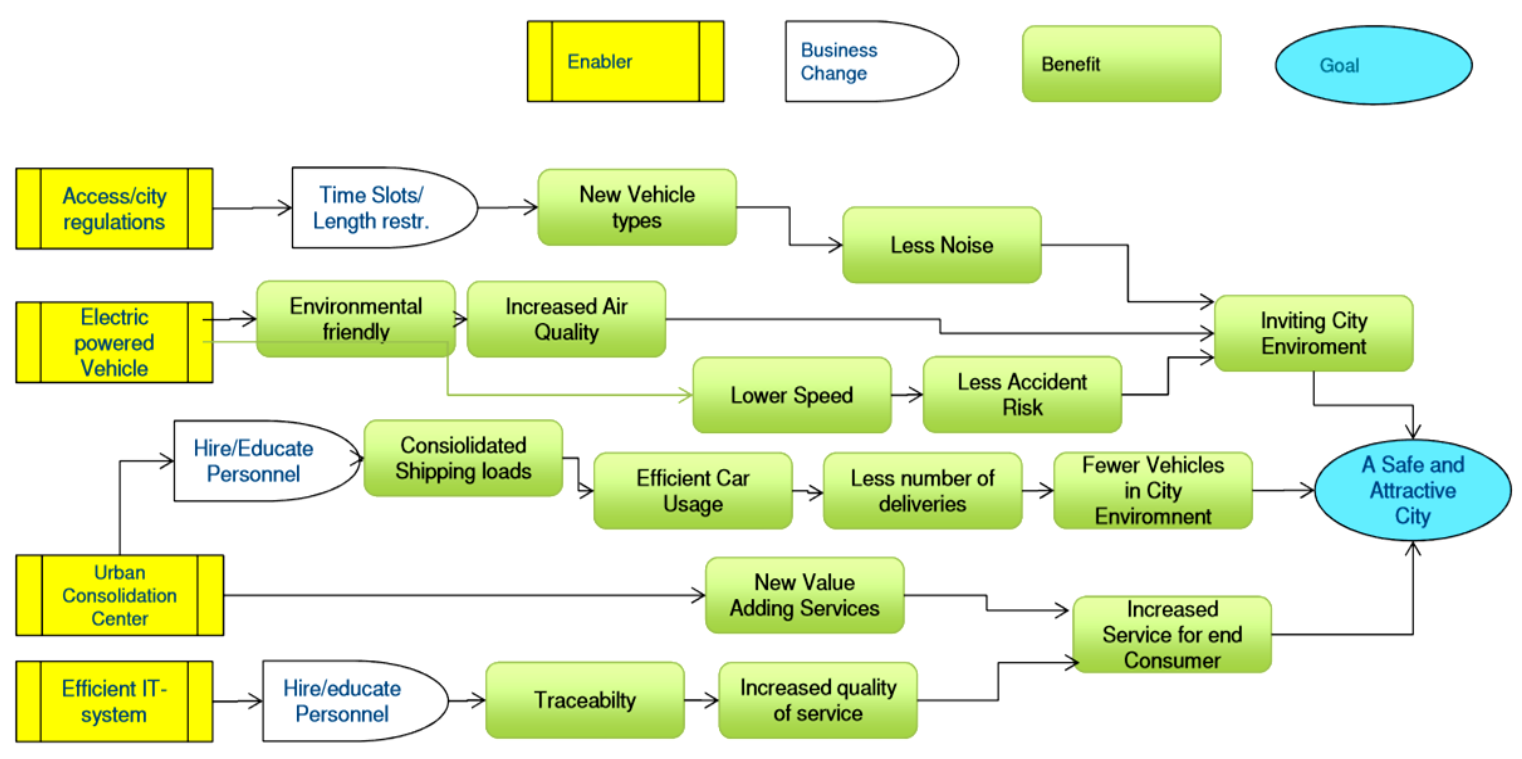

Fig. 1 Mobility flowchart in Gothenburg. Source: [10]

The benefits are new infrastructure that mediates timely deliveries at low cost and significant emission reductions [10].

\subsection{Amsterdam}

Deliveries are made via DHL shipping systems. Procedure - the ship can transport up to 20 couriers with their bicycles, thus delivering the shipments in an environmentally friendly way and are guided via a GPS application in a smartphone [8].

\subsection{Paris, Roma}

They prefer night-time deliveries, thus taking advantage of optimal delivery times, without interruptions and traffic jams in the morning [8].

\subsection{Greek cities}

Greek cities using a UCC (Urban Road Centres) strategy that can effectively deliver to business. The core/centre is the logistic centre (see Figure 2) [8]. 

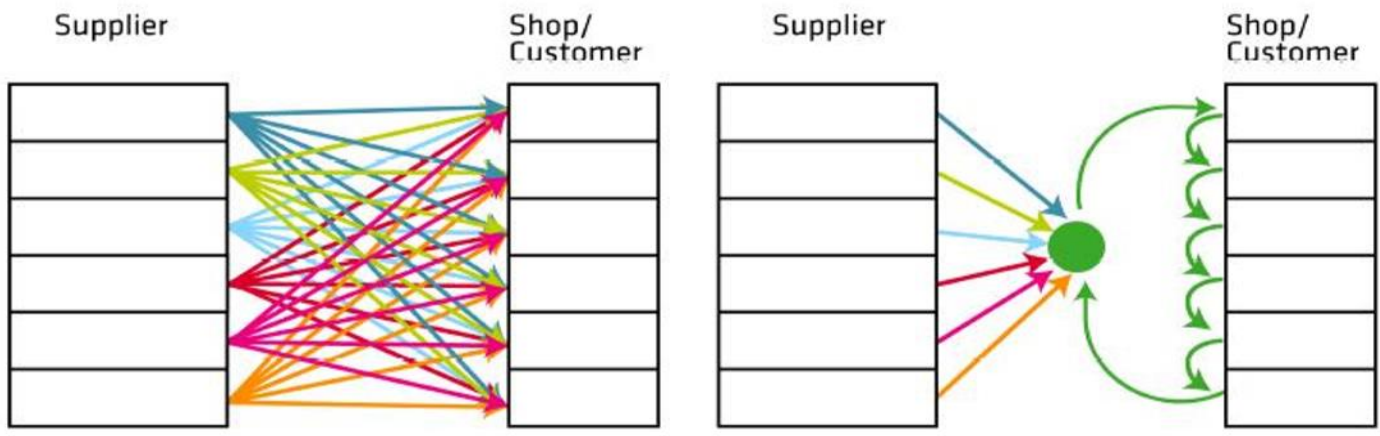

Fig. 2 UCC concept. Source: [8]

\subsection{Tokyo and Japan}

Countries and cities with a high population and polluted air (smog) prefer underground transport, the so-called "Underground Freight Transport" [8].

\subsection{Prague}

The strategy for the development of the city of Prague in the field of mobility is called Morgenstadt City Lab Prague. The aim of the project is to identify the strengths and weaknesses of traffic in the capital, identify performance indicators, measure them, and then propose recommendations together with a strategy for improvement. Current shortcomings in the field of mobility include [11]:

- little cooperation between the city and the region,

- congestion,

- non-use of mobile applications,

- residents consider travelling by car to be "more attractive".

Although travelling by car is more attractive in terms of standards of living and status, surveys point to a growing trend in using subway. In 2012, this means of transport was used by up to 700 million passengers. The implementation of transport terminals, the modernization of transport on Wenceslas Square and the creation of a modern district should solve the problems. Goals are currently set until 2050.

Apart from Prague, agglomerations such as Brno, Pardubice, Kolín, towns in the MoravianSilesian Region are also included among the "best practice" cities [12]. The Mendel University in Brno conducted a survey on smart cities, which showed that the areas of the greatest interest are transport processes and that stakeholders feel little support from the state and are not satisfied with the low awareness of the issue [13]. 


\subsection{Debrecen}

Debrecen plans to create a so-called "City management centre", which will uniformly manage "smart" industries and activities. Technology promotion in the given agglomeration is at a high level, with presentations, trainings and community meetings held regularly [14].

The aim of the city management is to cooperate with stakeholders to create a modern city with a high quality of life of its inhabitants. In terms of mobility, the following technologies have been introduced [14]:

- free Wi-Fi at stations and on buses, trolleybuses,

- e-tickets,

- "smart" pedestrian crossings,

- "smart" parking,

- WAZE application for easy navigation and location in the city, currently used by 80 million inhabitants.

\subsection{Warsaw}

Strategic management has created a clear overview of the understanding the smart city and its components. The basic goals are economic growth, sustainability, quality of life, and ecology. Key areas of mobility in Warsaw include [15]:

- efficient public transport,

- low emissions,

- new technologies that bring sustainable solutions.

The management cooperates mainly with the inhabitants and uses their creative ideas. The essence of success is to build trust and communicate available information to stakeholders. Significant mutual assistance, support, and promotion currently prevail [15].

Veturilo is a "bike sharing" system. Warsaw has 355 bicycle exchange stations; in 2017, the technology was used by 610,000 inhabitants. The system of bicycle paths has $500 \mathrm{~km}$. People get travel or parking tickets via a mobile application. Car sharing and support for electro mobility are also popular - it is planned to introduce 140 autonomous buses in the form of a R\&D\&I project. The platform will analyse the data, determine the effective path - "best practice" from Dublin.

Warsaw will develop a strategy set for 2030. The new model will create the right conditions for cooperation, innovation and a rapid response to change. PwC consultants predict a $10 \%$ increase in the population of the Polish city by 2035 . The development will include knowledge of management and design. Looking at the "Smart City" Warsaw presents a social, economic, environmental, and technical aspect [15]. 


\section{Discussion}

The following benefits represent some of the results of Smart city implementation in the aforementioned case studies:

- reduction of time necessary to move from point $\mathrm{A}$ to point $\mathrm{B}$,

- efficient search for a parking space,

- timely connections,

- reduction of tailbacks,

- elimination of accidents,

- early warning systems,

- real-time data from sensors, traffic lights,

- support for the trend in electro mobility, autonomous vehicles,

- predictive analyses of transport infrastructure,

- efficient supply chain for both the private and public sectors,

- Car and bicycle sharing

- reduction of transport costs,

- time savings of 15 to 30 minutes,

- higher quality of life of the population,

- support for management and decision-making at all levels of the city,

- reduction and improvement of logistics operations in cities.

The limitations of intelligent logistic models implementation can include local specific conditions in connection with the natural background and geographical location of a given city, including the current form of its infrastructure. Cities with access to the sea or rivers will use differently conceived models than those that do not have this transport alternative available (inland cities, mountain areas, etc.). Another related negative is the attitude of citizens towards new technologies, the level of awareness or social, cultural, and behavioral aspects that affect innovation activities in Smart Cities on a global scale. From the secondary analysis, it follows that it is appropriate for cities to implement logistic models according to the example from Mulligan .

Urban transport covers four "P" - the Public interest, the Private sector, the Population and the Place, thus creating a common interest in achieving the set goal [16].

Compared to 2012, "Smart Cities" generated $13.9 \%$ more profit (from 0.7 trillion to an estimated 2.1 trillion in 2020). The effects are growth, market opportunities, less risk, investment, and innovation [16-19]. 


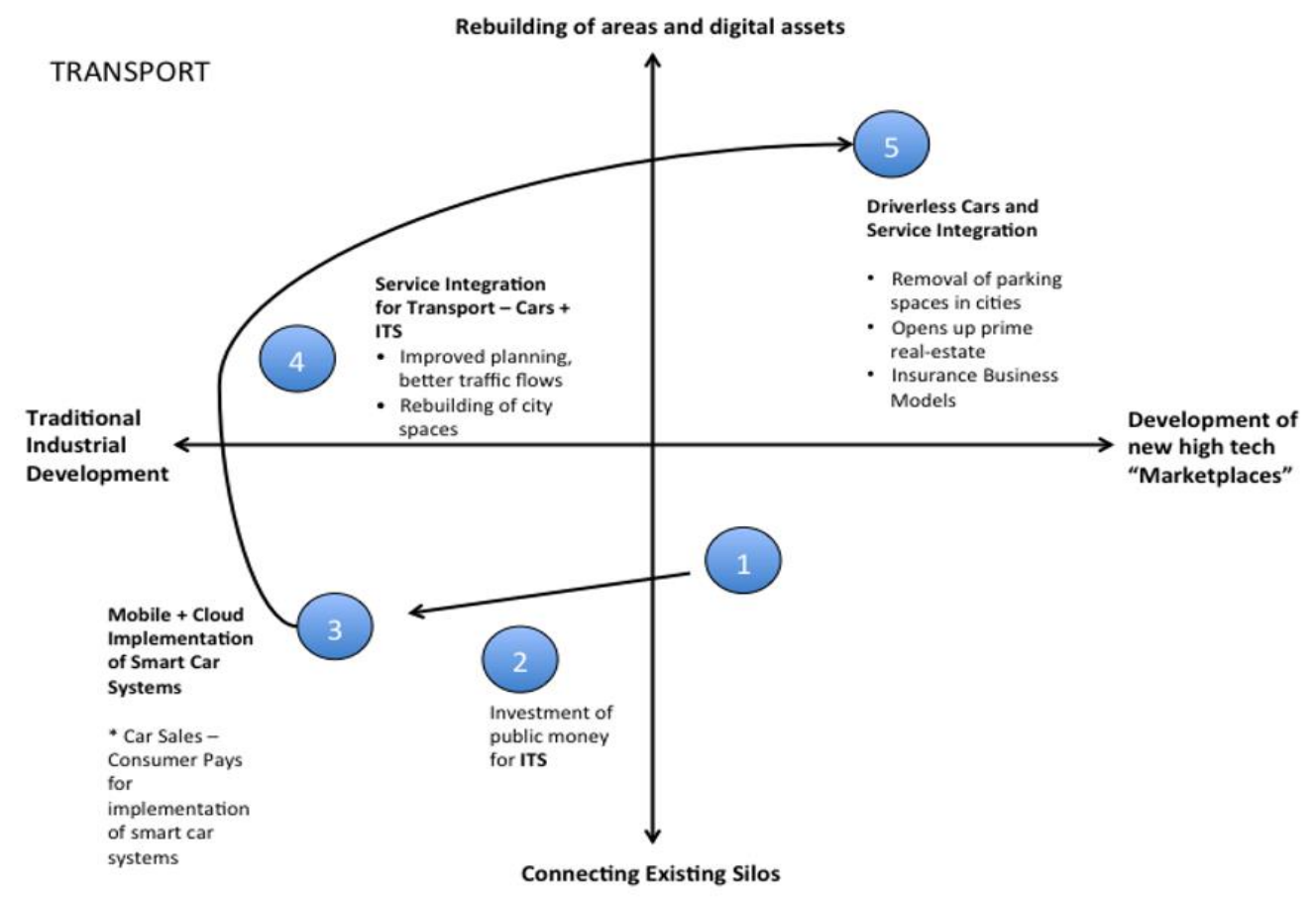

Fig. 3 Business model of mobility in the field of Smart City. Source: [16]

The recommended business model for logistics processes consists of 5 steps. The shift from 1 to 3 is based on investments in the field of information technology. The implementation of mobile applications and cloud storage, together with the integration of current processes, will create a basis for the deployment of autonomous cars, deliveries and real-time information acquisition (see Figure $3)$.

\section{Conclusion}

Implementing logistic models in smart cities brings added value to all Smart City stakeholders, i.e. citizens who generate data through applications, managers who can effectively carry out management and decision-making processes based on the data obtained, reduce logistics costs, and deliver products quickly and efficiently to cities that model the quality of life for all. The use of modern logistics technologies generates a competitive advantage based on the strategy win-win. The cases/examples of best practice cases pointed not only to the benefits of introducing modern logistics processes, but also to possible limitations in the form of local and cultural specific conditions. The application of the generally recommended model eliminates possible differences and problems, thus contributing to the development of a sustainable city in the field of mobility anywhere in the world. 


\section{Acknowledgments}

This publication was realized with support of the Operational Programme Integrated Infrastructure in frame of the project: Intelligent systems for UAV real-time operation and data processing, code ITMS2014+: 313011 V422 and co-financed by the European Regional Development Found.

\section{References}

[1] Falát, L. \& Holubčík, M. (2017). The influence of marketing communication on financial situation of the company - a case from automobile industry. Procedia Engineering 192, 148153.

[2] Závodská, A., Jurošková, Z. \& Soviar, J. (2015). Management of cooperation activities in university science park. Lecture Notes in Business Information Processing. 224, 770-779.

[3] Kubina, M. \& Lendel, V. (2012). Hexagonal stellar model of CRM-key elements influencing the CRM building. E a M: Ekonomie a Management 15, 57-72.

[4] McKinsey Global Institute. Smart City. Retrieved July 22, 2020, from https://www.slideshare.net/MediatelecomPolicyan/smart-cities-digital-solutions-for-a-morelivable-future.

[5] Falát, L. \& Holubčík, M. (2019). Review on teamwork: General and scientific perspective. In 33rd International Business Information Management Association Conference: Education Excellence and Innovation Management through Vision 2020, 10 - 11 April 2019 (pp. 59315936). Granada; Spain.

[6] Pollák, F., Dorčák, P., Markovič, P. \& Soviar, J. (2019). Innovative approaches to the reputation management in the tourism sector. In IDIMT 2019: Innovation and Transformation in a Digital World - 27th Interdisciplinary Information Management Talks, 4 - 6 September 2019 (pp. 285-292), Kutna Hora; Czech Republic.

[7] Holubčík, M., Bubelíny, O \& Kubina, M. (2020). A study of the impacts of technological innovations on cooperation cases. Lecture Notes of the Institute for Computer Sciences, Social-Informatics and Telecommunications Engineering, LNICST 332, 296-303.

[8] Mallinddretos, G., Mavrommati, S. \& Bakogianni, M.-A. (2018). City Logistics Models in the framework of Smart Cities. In $4^{\text {th }}$ International Conference on Supply Chains, September 2018 (pp. 14-15) Katerini Greece.

[9] Lee, S.K., Kwon, H.R., Cho, H., Kim, J. \& Lee, D. (2016). International Case Studies of Smart Cities. Singapore, Republic of Singapore. Retrieved July 22, 2020, from 
https://publications.iadb.org/publications/english/document/International-Case-Studies-ofSmart-Cities-Singapore-Republic-of-Singapore.pdf.

[10] Thorén, A. (2015). Focus on a sustainable business model for smart city delivery. Retrieved July 22, 2020， from http://smartset-project.eu/sites/default/files/int_downloads/ 08_SMARTSET_Conference_Graz_THOREN.pdf.

[11] Radecki, V.A., Fanderl, N., Buttler, M. \& Krylova, E. (2016). City Lab Prague. Retrieved July 23, 2020, from http://www.iprpraha.cz/uploads/assets/dokumenty/ssp.

[12] Kubeš, F. (2018). Zkušenosti ze Smart Cities v ČR. Retrieved July 23, 2020, from https://smartcitiesklub.sk/wp-content/uploads/2018/02/SC2018-4-2-Kubes.pdf.

[13] Grega, L. (2018). Analýza aktuální úrovně zapojení ČR do konceptu smart city a smart region v souvislosti s novými trendy, včetně návrhů opatření. Retrieved July 23, 2020, from https://www.vlada.cz/assets/evropske-zalezitosti/aktualne/Zaverecnazprava_Smart_City_a_Smart_Region.pdf.

[14] Mátyus, L. (2018). Debrecen - Smart city. Retrieved July 23, 2020, from http://smartcity.debrecen.hu/en.

[15] Warsaw - towards a Smart City. (2018). Retrieved July 23, 2020, from http://firma.um. warszawa.pl/wp-content/uploads/2018/01/WARSAW-TOWARDS-A-SMART-CITY2018.pdf.

[16] Mulligan, C. (2014). Smart City Business Models. Retrieved July 23, 2020, from https://smart-circle.org/wp-content/uploads/sites/3/2014/05/Masterclass-2-CatherineMulligan.pdf.

[17] Kundríková, J., Závodská, A. \& Soviar, J. (2016). Technology transfer - Case of Slovak academic environment. Lecture Notes of the Institute for Computer Sciences, SocialInformatics and Telecommunications Engineering, LNICST 166, 671-680.

[18] Varmus, M. \& Kubina, M. (2020). Impact of the proportion of foreign players' appearances on the success of football clubs in domestic competitions and european competitions in the context of new culture. Sustainability 12(1), 264.

[19] Uramova, J., Kubina, M., Segec, P. \& Paluch, P. (2012). ViRo - The online support tool for IP network oriented courses. In 10th IEEE International Conference on Emerging eLearning Technologies and Applications, 8-9 November 2012 (pp. 339-343). Stara Lesna; Slovakia. 